Jurnal REKSA: Rekayasa Keuangan, Syariah, dan Audit

p-ISSN: 2089-6581 | e-ISSN: 2614-3720

Vol. 06, No. 02, 2019, pp. 111-122

\title{
LEGALITAS MEREK DAGANG DAN KEMITRAAN USAHA PADA UNIT
} PERDAGANGAN BUMDES NIAGARA

\section{Trisa Nur Kania}

Fakultas Ilmu Sosial dan Ilmu Politik, Universitas Pasundan

Email: trisa.nurkania@unpas.ac.id

Latifah Adnani

Fakultas Ilmu Sosial dan Ilmu Politik, Universitas Pasundan

Email: latifah.adnani@unpas.ac.id

\begin{abstract}
Law Number 20 of 2016 in Indonesia regulates brands and geographical indications (hereinafter referred to as Trademark Law). For businesses, making an effort to legalize the brand of the products/services they sell is important, even though in reality, many business actors do not understand this. This study aims to find out, analyze and provide insight into knowledge and understanding of businesses about the importance of a product being given a trademark and legally legalized through trademark registration to the state. Other than that, the other purpose of this research is to provide business partners with an understanding of business partnerships. The research method uses case studies with the consideration that the focus of the research is on contemporary (present) phenomena in the context of real life. The results showed that the business actors did not understand the rules relating to trademark design and procedures for trademark registration and did not understand the business contract with business partners. Therefore, in order to help solve the problems faced by business actors, the community service activities are carried out in stages, namely: provide counseling on regulations and laws related to trademark and assistance in the procedure for trademark registration, as well as assistance in making business contracts with business partners.
\end{abstract}

Keywords : Legalize Brand, Business Partnerships.

\section{LATAR BELAKANG}

Salah satu kebijakan pemerintah di era pemerintahan Presiden Joko Widodo periode tahun 2014-2019 yang berkaitan dengan upaya pemerataan pembangunan ekonomi di tingkat desa adalah kebijakan tentang pemerintah desa yang diberi kewenangan untuk mengelola kegiatan ekonomi secara mandiri melalui lembaga ekonomi di tingkat desa. Satu diantaranya adalah kewenangan desa untuk mendirikan sebuah lembaga ekonomi yang disebut Badan Usaha Milik Desa (BUMDes). BUMDes menurut UU No 6 tahun 2014 adalah lembaga ekonomi yang didorong untuk berperan di desa. Pendirian BUMDes merupakan jalan untuk membentuk ekonomi pedesaan yang mandiri, seperti mengelola potensi desa dengan cara yang kreatif dan inovatif, yang dapat membuka lapangan kerja baru sehingga mampu menyerap tenaga kerja di pedesaan. Tujuan dari didirikannya 
Trisa Nur Kania, Latifah Adnani | Legalitas Merek Dagang dan Kemitraan Usaha ...

BUMDes adalah sebagai berikut : 1) Meningkatkan perekonomian desa; 2) Meningkatkan pendapatan asli desa; 3) Meningkatkan pengolahan potensi desa sesuai dengan kebutuhan masyarakat; 4) Menjadi tulang punggung pertumbuhan dan pemerataan ekonomi pedesaan. (PKDSP, 2007)

Sejak diundangkannya peraturan mengenai BUMDes, maka sampai dengan bulan Juni tahun 2018 telah berdiri sekitar 32.000 BUMDes di Indonesia. Akan tetapi dari jumlah sebanyak itu, kegiatan BUMDes yang dapat dikatakan sudah mampu berjalan dengan baik layaknya sebuah badan usaha ternyata baru dapat tercapai sekitar 7000 BUMDes (berdasarkan info dari Asosiasi BUMDes yang diakses pada tanggal 3 Agustus 2018) Kondisi tersebut menyiratkan sebuah kenyataan bahwa harapan pemerintah untuk terwujudnya kemandirian desa dalam bidang ekonomi dengan BUMDes sebagai aktor penggeraknya bukanlah suatu hal yang mudah. Jika melihat data di atas, maka dapat dikatakan bahwa secara kuantitas BUMDes yang aktif jauh lebih sedikit dibandingkan dengan jumlah BUMDes yang sudah didirikan. Walaupun masih banyak BUMDes yang aktivitas usahanya masih terbatas, ternyata ada BUMDes yang sudah mampu menjalankan usahanya dengan mandiri dan memiliki beberapa unit garapan usaha yang telah berhasil menggerakkan perekonomian desa serta memberdayakan dan melibatkan anggota masyarakat desa untuk bekerja di BUMDes dan ada juga yang melakukan kemitraan usaha dengan BUMDes. Tulisan ini selanjutnya akan menjelaskan tentang aktivitas bisnis di salah satu BUMDes yang terdapat di wilayah Kabupaten Bandung, yaitu di desa Wangisagara, kecamatan Majalaya. BUMDes ini bernama BUMDes Niagara yang didirikan pada tahun 1999. Niagara merupakan singkatan dari Berniaga di Wangisagara. Sejak didirikan BUMDes Niagara sudah menjalankan usahanya secara mandiri, yaitu dengan dibentuknya Unit Usaha Pengelolaan Kios Pasar. Pengelolaan kios pasar merupakan garapan usaha pertama BUMDes Niagara. Sampai dengan saat ini sudah bertambah dengan beberapa unit garapan usaha yang lain, yaitu : Unit Simpan Pinjam, Unit Pelayanan Penjualan On Line dan Unit Perdagangan. Unit Perdagangan menjual dua jenis produk yaitu air mineral dan sandal untuk wanita dewasa dan laki-laki dewasa. Sandal tersebut merupakan produk dari BUMDes Niagara dan sudah diberi merek Tumaninah. Produk sandal ini adalah produk yang dihasilkan dari kemitraan usaha antara BUMDes Niagara sebagai investor dengan Bapak Roni Loviansyah sebagai pihak pembuat sandal. Sandal Tumaninah telah menjadi garapan usaha Unit Perdagangan BUMDes Niagara sejak bulan Januari 2019. Berdasarkan wawancara dan observasi yang telah dilakukan peneliti dengan pengurus BUMDes Niagara, diketahui bahwa Unit Perdagangan BUMDes menghadapi kendala di dalam memasarkan produk sandal Tumaninah. Diungkapkan oleh pengurus BUMDes bahwa pemasarannya masih terbatas di desa setempat dan belum menghasilkan keuntungan seperti yang diharapkan oleh BUMDes. Oleh sebab itu berdasarkan masalah yang telah diketahui, maka akan dikaji lebih lanjut mengenai kendala-kendala yang dihadapi oleh BUMDes Niagara dalam memasarkan produk sandal Tumaninah, serta menganalisis peluang-peluang yang dapat dilakukan untuk mengatasi permasalahan yang dihadapi oleh BUMDes Niagara tersebut.

Pengkajian tentang faktor-faktor yang menjadi kendala di dalam memasarkan produk Sandal Tumaninah menjadi penting untuk dapat dicari solusi yang tepat sehingga

Jurnal REKSA: Rekayasa Keuangan, Syariah, dan Audit, Vol. 06, No. 02, 2019, pp 111-122 | 112 
Trisa Nur Kania, Latifah Adnani | Legalitas Merek Dagang dan Kemitraan Usaha ...

akan dapat dilakukan tindakan-tindakan yang sesuai dengan kebutuhan penyelesaian permasalahan tersebut. Dengan demikian uraian yang disampaikan di dalam tulisan ini merupakan hasil penelitian yang ditindaklanjuti oleh kegiatan pengabdian kepada masyarakat dalam bentuk bantuan-bantuan yang sesuai dengan kebutuhan BUMDes Niagara pada Unit Perdagangan, khususnya dalam menangani pemasaran produk sandal Tumaninah. Tujuan dari kegiatan ini adalah untuk mengetahui, menganalisis dan ikut serta membantu menyelesaikan permasalahan yang dihadapi Unit Perdagangan BUMDes Niagara, sehingga harapan Unit Perdagangan BUMDes Niagara ke depan akan menjadi terbuka lebih lebar untuk memasarkan produk sandal Tumaninah dengan daya jangkau pemasaran yang lebih luas. Berdasarkan hasil wawancara dengan pengurus BUMDes Niagara, dapat diketahui bahwa masalah-masalah yang berkaitan dengan pemasaran Sandal Tumaninah adalah sebagai berikut :

1. Terdapat kekeliruan di dalam label/merek sandal Tumaninah yang disebabkan karena kurangnya pengetahuan pengurus BUMDes tentang aturan-aturan yang berkaitan dengan desain label/merk dagang dari produk yang dijualnya. Dimana pada label Tumaninah yang sudah jadi tersebut menggunakan kata "sandal", yang semestinya kata "sandal" tersebut tidak perlu ada di label. Selain itu ada juga kata "Niagara” yang menunjukkan sebuah tempat yang sudah dikenal di dunia dan menurut aturan tentang merek hal tersebut tidak diperbolehkan.

2. Terdapat kekeliruan di dalam surat perjanjian kerjasama/kontrak bisnis antara pihak BUMDes dengan pihak pembuat sandal yang merupakan mitra kerja BUMDes. Dimana dalam hal ini ada beberapa kalimat yang harus diperbaiki mengikuti aturan yang semestinya di dalam format kontrak bisnis.

3. Belum dilakukan pendaftaran merek dagang sandal Tumaninah, karena belum memahami tatacara dalam pendaftarannya kepada negara.

4. Belum dilakukan upaya promosi yang gencar karena pihak BUMDe Niagara belum merasa percaya diri untuk memasarkan produk sandal Tumaninah.

Berdasarkan pada kondisi yang dialami oleh pengurus BUMDes Niagara tersebut di atas, maka rencana tim pelaksana kegiatan untuk membantu penyelesaian masalah yang dihadapi Bumdes akan dilakukan secara bertahap yaitu sebagai berikut :

1. Dilakukan penyuluhan tentang merek dagang dan aturan-aturan/undang-undang yang berlaku pada saat ini terkait dengan pembuatan desain merek dagang dan pendaftaran merek dagang serta dilakukan penjelasan dan arahan tentang pembuatan desain merek dagang Tumaninah yang baru agar tidak menyalahi aturan dan menjadi sesuai dengan peraturan yang telah ditentukan oleh undangundang merek.

2. Dilakukan penyuluhan tentang kontrak bisnis kepada pengurus BUMDes Niagara

3. Dilakukan pendampingan pada saat pembuatan surat kuasa untuk pendaftaran merek dagang sandal Tumaninah yang baru kepada negara dalam hal ini Ditjen HKI Kemenkumham Wilayah propinsi Jawa Barat. 
Trisa Nur Kania, Latifah Adnani | Legalitas Merek Dagang dan Kemitraan Usaha ...

4. Diberikan saran dalam strategi pengembangan pemasaran sandal Tumaninah dengan cara kekinian, sesuai dengan kemajuan teknologi informasi dan komunikasi.

Berkaitan dengan permasalahan yang telah diketahui, maka tinjauan teoritis yang akan diuraikan antara lain penjelasan tentang merek dagang yang terdapat di dalam aturan hukum tentang merek yang berlaku di Indonesia (UU No 20/2016) serta mengenai kemitraan usaha, khususnya yang berkaitan dengan kontrak bisnis/perjanjian bisnis.

\section{KAJIAN LITERATUR}

Kegiatan pemasaran pada perusahaan/badan usaha memegang peranan yang sangat penting, sebab kesuksesan atau kegagalan pemasaran dapat menjadi kunci dari keberhasilan setiap usaha. Apabila barang/jasa yang diproduksi tidak disukai konsumen, maka kondisi tersebut akan merugikan perusahaan/badan usaha. Sebaliknya, jika barang/jasa disukai konsumen, maka akan mengalami peningkatan dalam produksi dan penjualan, sehingga akan berimbas pada kenaikan keuntungan perusahaan. Berkaitan dengan barang atau jasa yang diproduksi oleh sebuah perusahaan/badan usaha, maka salah satu perkembangan yang aktual dan mendapatkan perhatian sejak belasan tahun terakhir ini adalah kecenderungan semakin meluasnya wilayah yang terdampak oleh globalisasi dalam berbagai bidang kehidupan manusia sehingga menantang manusia untuk menyelesaikan masalah-masalah baru yang muncul karena efek globalisasi tersebut, khususnya globalisasi dalam bidang ekonomi. Bahkan dengan perkembangan teknologi informasi dan transportasi yang semakin canggih telah menjadikan peningkatan dalam kegiatan di sektor perdagangan yang sudah ada pada skala pasar tunggal dunia.

Beberapa faktor yang harus menjadi unggul dalam daya saing dengan sesama pelaku usaha di pasar global antara lain kualitas produk/jasa dan kualitas sumber daya manusia. Salah satu unsur yang harus diupayakan untuk tampil menarik dan dilindungi secara sah oleh hukum yang berlaku di sebuah negara adalah merek dari sebuah produk atau jasa yang dikeluarkan oleh sebuah perusahaan atau badan usaha. Dalam hal ini menurut Ahmadi Miru (2005:1), "merek menjadi bagian dari kualitas produk yang memegang peranan penting sehingga memerlukan system pengaturan yang memadai." Pentingnya peraturan mengenai merek ini merupakan sebuah hal yang harus diperjuangkan agar dapat diketahui dan dipahami oleh masyarakat pelaku usaha karena jika berdasar pada penelitian sebelumnya yaitu tentang kesadaran hukum para pengrajin batik Pekalongan terhadap kepemilikan merek terdaftar ternyata masih rendah. Mereka belum sadar akan pentingnya hak kekayaan intelektual, khususnya merek. Untuk itu perlu dilakukan penelitian mendalam mengingat belum banyaknya warga yang memahami dan memiliki merek terdaftar. (Endang Purwaningsih Nelly Ulfah Anisa Riza Nurul Fajri Chikmawati \& Fakultas, n.d.). Begitu pula dengan kajian Legalitas Merek pada UMKM Munaku Sulam Pita di Semarang (2018) diketahui bahwa hambatan dalam pendaftaran merek yang dihadapi Ibu Anna dan rekan-rekan pelaku usaha mikro adalah mengenai keterbatasan dana dan pendampingan (Sukmadewi, 2018). Dengan demikian tampak bahwa meskipun pelaku 
Trisa Nur Kania, Latifah Adnani | Legalitas Merek Dagang dan Kemitraan Usaha ...

usaha sudah memiliki kesadaran tentang merek dagang dari produk yang dihasilkannya, tetapi kesadaran untuk mendaftarkan merek tersebut masih rendah.

Kesadaran tentang merek dagang yang masih rendah menjadi kondisi yang memprihatinkan karena di Indonesia sebenarnya sudah diterbitkan undang-undang yang terkait dengan merek sejak tahun 1992. Bahkan untuk saat ini telah terbit peraturan tentang merek yang telah direvisi yaitu Undang-undang No 20 Tahun 2016. Berdasarkan UU tersebut, dalam pasal 1 ayat 1, yang dimaksud dengan merek adalah (“www.hukumonline.com/pusatdata," 2016) ${ }^{1}$ " Tanda yang dapat ditampilkan secara grafis berupa gambar, logo, nama, huruf, angka, susunan warna, dalam bentuk 2 (dua) dimensi dan/atau 3 (tiga) dimensi, suara, hologram, atau kombinasi dari 2 (dua) atau lebih unsur tersebut untuk membedakan barang dan/atau jasa yang diproduksi oleh orang atau badan hukum dalam kegiatan perdagangan barang dan/atau jasa". Selanjutnya pada ayat 2 disebutkan bahwa "Merek dagang adalah merek yang digunakan pada barangbarang yang diperdagangkan oleh seseorang atau beberapa orang secara bersama-sama atau badan hukum untuk membedakan dengan barang sejenis lainnya". Merujuk pada penjelasan tentang merek dan merek dagang menurut undang-undang tersebut, maka menjadi penting bagi seorang pelaku usaha atau sebuah badan usaha untuk memiliki merek dagang bagi produk yang dijualnya. Mengapa penting? berikut akan diuraikan faktor-faktor penyebabnya, yaitu (info@prolegal.id) : 1). Menjadi pendongkrak nilai jual asset perusahaan. 2) Menjadi jaminan atas mutu produk atau jasa. 3). Sebagai alat promosi. 4). Menjadi tanda pengenal produk yang juga dapat berfungsi sebagai pembeda antar produk sejenis yang beredar di pasaran. Sehubungan dengan pentingnya merek dagang yang harus dimiliki oleh pelaku usaha/perusahaan atau badan usaha, maka mendaftarkan merek yang telah dimiliki pelaku usaha menjadi hal yang tidak kalah penting dari membuat desain merek dagang, sehingga perlu diperhatikan syarat-syarat yang harus disiapkan dalam upaya mendaftarkan merek dagang tersebut. Adapun tata cata permohonan pendaftaran merek, menurut UU No 20/2016 pasal 4 ayat 1-9 adalah sebagai berikut :

(1) Permohonan pendaftaran Merek diajukan oleh Pemohon atau Kuasanya kepada Menteri secara elektronik atau non-elektronik dalam bahasa Indonesia.

(2) Dalam Permohonan sebagaimana dimaksud pada ayat (1) harus mencantumkan: a. tanggal, bulan, dan tahun Permohonan; b. nama lengkap, kewarganegaraan, dan alamat Pemohon; c. nama lengkap dan alamat Kuasa jika Permohonan diajukan melalui Kuasa; d. warna jika Merek yang dimohonkan pendaftarannya menggunakan unsur warna; e. nama negara dan tanggal permintaan Merek yang pertama kali dalam hal Permohonan diajukan dengan Hak Prioritas; dan, f. kelas barang dan/atau kelas jasa serta uraian jenis barang dan/atau jenis jasa.

(3) Permohonan ditandatangani Pemohon atau Kuasanya.

(4) Permohonan sebagaimana dimaksud pada ayat (1) dilampiri dengan label Merek dan bukti pembayaran biaya.

(5) Biaya Permohonan pendaftaran Merek ditentukan per kelas barang dan/atau jasa. 
Trisa Nur Kania, Latifah Adnani | Legalitas Merek Dagang dan Kemitraan Usaha ...

(6) Dalam hal Merek sebagaimana dimaksud pada ayat (4) berupa bentuk 3 (tiga) dimensi, label Merek yang dilampirkan dalam bentuk karakteristik dari Merek tersebut.

(7) Dalam hal Merek sebagaimana dimaksud pada ayat (4) berupa suara, label Merek yang dilampirkan berupa notasi dan rekaman suara.

(8) Permohonan sebagaimana dimaksud pada ayat (1) wajib dilampiri dengan surat pernyataan kepemilikan Merek yang dimohonkan pendaftarannya.

(9) Ketentuan lebih lanjut mengenai biaya Permohonan sebagaimana dimaksud pada ayat (5) diatur dengan Peraturan Pemerintah. ("www.hukumonline.com/ pusatdata," 2016).

Selanjutnya di bawah ini diuraikan tentang syarat dan tahapan pendaftaran merek, yaitu sebagai berikut (info@prolegal.id):

1. Penelusuran merek, yaitu upaya mencari tahu apakah merek yang akan didaftarkan telah menjadi hak milik dan/atau telah terdaftar atas nama pihak lain. Penelusuran ini sangat penting untuk menghindari potensi ditolaknya permohonan pendaftaran merek dan juga resiko lain yaitu konflik perdata.

2. Persyaratan Pengajuan Permohonan, yaiut persiapan yang dibutuhkan dalam pendaftaran merek, yaitu sebagai berikut :

a. Formulir pengajuan yang telah diisi oleh pemohon

b. Menyiapkan contoh merek sebanyak 5 buah yang berukuran maksimal $9 \mathrm{x}$ $9 \mathrm{~cm}$ dan minimal $2 \times 2 \mathrm{~cm}$ :

c. Menyiapkan daftar barang atau jasa yang akan diberi merek sesuai dengan klasifikasi kelas merek ;

1. Sebagai informasi, setiap merek dapat didaftarkan di berbagai kelas, namun akan berimplikasi pada biaya tentunya. Hal mana dalam setiap pengajuan merek, didaftarkan di kelas yang disesuaikan dengan kegiatan usaha, produk dan/atau layanan jasa dan didaftarkan dalam sub-kelas yang maksimal dapat didaftarkan dalam 10 (sepuluh) sub-kelas :

2. Surat pernyataan kepemilikan dari merek:

3. Surat kuasa(apabila dalam pengurusan dikuasakan kepada pihak ke-tiga)

4. Fotocopy Kartu Tanda Penduduk (KTP) dan Nomor Pokok Wajib Pajak (NPWP) untuk pemohon perorangan: atau

5. Fotocopy Akta Pendirian, Akta perubahan (jika ada), SK Pendirian, SK Perubahan (jika ada), Nomor Pokok Wajib Pajak (NPWP), Surat Keterangan Domisili, Ijin Usaha, Tanda Daftar Perusahaan (TDP), persyaratan ini diberlakukan khusus bagi pemohon berbentuk badan usaha.

3. Prosedur Pendaftaran Merek, setelah seluruh persyaratan dan hasil penelusuran merek positif maka dapat dilakukan langsung pendaftaran merek tersebut. 
Trisa Nur Kania, Latifah Adnani | Legalitas Merek Dagang dan Kemitraan Usaha ...

Jadi setelah merek dagang dimiliki oleh pelaku usaha/perusahaan/badan usaha maka merek tersebut harus didaftarkan ke kantor merek agar mendapat perlindungan hukum dari negara dan tidak dapat ditiru oleh orang lain. Sementara itu, di dalam aktivitas bisnis selalu terbuka kemungkinan adanya sebuah hubungan kerjasama bisnis antara seorang pelaku usaha/perusahaan/badan usaha dengan seseorang atau pihakpihak tertentu yang dipandang layak atau cocok di dalam melakukan sebuah kerjasama bisnis setelah ada kesepakatan diantara mereka. Di dalam istilah bisnis hal seperti itu disebut sebagai kemitraan usaha. Menurut M. Jafar Hafsah (2000:43) yang disebut dengan kemitraan usaha adalah "Suatu strategi bisnis yang dilakukan oleh dua pihak atau lebih dalam jangka waktu tertentu untuk meraih keuntungan bersama dengan prinsip saling membutuhkan dan saling membesarkan". Kemitraan diharapkan dapat dilaksanakan dengan hasil yang memuaskan, sehingga memerlukan pemahaman etika bisnis dari pihak-pihak yang terkait. Adapun dasar-dasar etika bisnis yang diperlukan dalam kemitraan usaha ada 6 (ibid : 47-50) yaitu : Karakter integritas dan kejujuran, Kepercayaan, Komunikasi yang terbuka, Adil, Keinginan pribadi dari pihak yang bermitra, Keseimbangan antara insentif dan resiko. Selanjutnya mengenai manfaat dari kemitraan (ibid:54-62) adalah sebagai berikut: Produktivitas, Efisiensi, Jaminan kualitas, kuantitas dan kontinuitas, Resiko, Sosial, Ketahanan ekonomi nasional. Mengenai tujuan dari kemitraan usaha dapat diuraikan sebagai berikut: 1) Meningkatkan pendapatan usaha kecil dan masyarakat. 2). Meningkatkan perolehan nilai tambah bagi pelaku kemitraan. 3) Meningkatkan pemerataan dan pemberdayaan masyarakat dan usaha kecil. 4) Meningkatkan pertumbuhan ekonomi pedesaan, wilayah dan nasional, 5) Memperluas kesempatan kerja. 6) Meningkatkan ketahanan ekonomi nasional. Konsekuensi logis dari adanya kemitraan usaha adalah adanya kepentingan tentang kontrak bisnis yang harus jelas aturan mainnya karena akan berhubungan dengan ranah hukum jika ada salah satu pihak yang melanggar kontrak bisnis tersebut. Menurut Black, Henry Campbell dalam Munir Fuady (2012:9) dikemukakan bahwa yang dimaksud dengan kontrak adalah "suatu kesepakatan yang diperjanjikan (promissory agreement) diantara 2 (dua) pihak atau lebih pihak yang dapat menimbulkan, memodifikasi, atau menghilangkan hubungan hukum" serta ada juga pendapat lain (ibid) yang menyatakan bahwa " kontrak sebagai perjanjian atau serangkaian perjanjian di mana hukum memberikan ganti rugi terhadap wanprestasi dari kontrak tersebut dan oleh hukum, pelaksanaan dari kontrak tersebut dianggap suatu tugas yang harus dilaksanakan." Dengan demikian, kerjasama usaha yang dilakukan melalui kemitraan usaha merupakan upaya yang dapat dilakukan dalam rangka mengisi kekurangan-kekurangan yang sangat mungkin dialami oleh pihak-pihak yang terlibat dalam kegiatan usaha, seperti : modal, tenaga ahli di bidang tertentu, bahan baku, mesin/ alat-alat produksi atau mungkin faktor-faktor yang lainnya. Tetapi tetap harus diperhatikan konsekuensi hukum yang akan timbul, jika salah satu pihak yang bermitra melakukan tindakan wanprestasi. 
Trisa Nur Kania, Latifah Adnani | Legalitas Merek Dagang dan Kemitraan Usaha ...

\section{METODA PENELITIAN}

Metode penelitian yang digunakan adalah metode penelitian Studi Kasus dengan pendekatan kualitatif. Metode Studi Kasus menurut Raharjo (2017:3) adalah "suatu rangkaian kegiatan ilmiah yang dilakukan secara intensif, terinci dan mendalam tentang suatu program, peristiwa, dan aktivitas, baik pada tingkat perorangan, sekelompok orang, lembaga atau organisasi untuk memperoleh pengetahuan mendalam tentang peristiwa tersebut". Biasanya peristiwa yang dipilih dalam metode studi kasus adalah hal yang aktual, yang sedang berlangsung saat ini. Sedangkan menurut Yin (2015:1), “ Studi kasus merupakan strategi yang lebih cocok bila pokok pertanyaan suatu penelitian berkenaan dengan how atau why, apabila peneliti hanya memiliki sedikit peluang untuk mengontrol peristiwa-peristiwa yang akan diselidiki dan bilamana fokus penelitiannya terletak pada fenomena kontemporer (masa kini) di dalam konteks kehidupan nyata". Objek penelitian berlokasi di desa Wangisagara, Kecamatan Majalaya, Kabupaten Bandung. Secara lebih spesifik, ruang lingkup penelitian adalah tentang kegiatan bisnis yang dilakukan di Unit Perdagangan yang ada di dalam Badan Usaha Milik Desa (BUMDes) Niagara. Bahan dan alat utama dari penelitian adalah data lapangan yang dapat diperoleh oleh tim peneliti melalui informan dari lapangan yang yaitu Ibu Neneng dan Bapak Roni . Adapun teknik pengumpulan data dilakukan dengan cara:

1). Wawancara dengan informan.

2) Observasi lapangan dan dokumentasi di rumah Bapak Roni yang menjadi tempat pembuatan sandal dan tahap packing yang dilakukan di Unit Perdagangan, kantor BUMDes Niagara.

3) Dokumentasi dari aktivitas yang dilakukan pengurus BUMDes berkaitan dengan kegiatan penyuluhan peraturan merek dagang dan kontrak bisnis. Dengan demikian, maka jenis data yang dikumpulkan adalah data primer, data sekunder serta dari studi literatur. Variabel penelitian yang digunakan adalah Merek dagang yang dirujuk dari UU No 20 Tahun 2016 dan buku yang mengupas tentang hukum merek dan cara mudah mempelajari merek. Sedangkan konsep mengenai Kemitraan Usaha tim peneliti merujuk dari Hafsah. Adapun analisis data yang dilakukan merujuk pada pendapat Bogdan (dalam Sugiyono,2017:244) yang mengatakan bahwa " Analisis data adalah proses mencari dan menyusun secara sistematis data yang diperoleh dari wawancara, catatan lapangan dan bahan-bahan lain, sehingga dapat mudah dipahami, dan temuannya dapat diinformasikan kepada orang lain. Analisis data dilakukan dengan mengorganisasikan data, menjabarkannya ke dalam unit-unit, melakukan sintesa, melakukan ke dalam pola, memilih mana yang penting dan yang akan dipelajari dan membuat kesimpulan yang dapat diceritakan kepada orang lain”.

\section{HASIL DAN PEMBAHASAN}

Setelah diketahui permasalahan yang dialami oleh Unit Perdagangan BUMDes Niagara, maka bantuan kemudian dilaksanakan secara bertahap. Hal tersebut dilakukan karena proses untuk menyelesaikan permasalahan terlebih dahulu memerlukan sebuah 
Trisa Nur Kania, Latifah Adnani | Legalitas Merek Dagang dan Kemitraan Usaha ...

pemahaman baru bagi objek penelitian, dalam hal ini proses pemahaman dari pengurus BUMDes menjadi penting untuk menjadi landasan adanya tindakan berikutnya yang akan dilakukan oleh pengurus BUMDes dalam rangka memproses penyelesaian masalah yang dihadapi pada Unit Perdagangan di BUMDes Niagara. Oleh sebab itu, setelah disepakati bahwa akan dilakukan upaya penyelesaian permasalahan, maka disusunlah secara bertahap urutan penyelesaian permasalahan. Adapun hasil penelitian dan pembahasannya serta dokumentasi pendukung di lapangan adalah sebagai berikut :

Permasalahan ke-1 berkaitan dengan kekeliruan di dalam label/merek sandal Tumaninah. Berdasarkan wawancara yang dilakukan di objek penelitian, maka diketahui bahwa pengurus BUMDes Niagara, yaitu Ibu Neneng, memang belum mengetahui tentang adanya peraturan tentang desain merek. Hal tersebut disebabkan karena Ibu Neneng memang masih awam dan tidak mengetahui tentang aturan dalam membuat desain merek. Guna menyelesaikan ketidaktahuan Ibu Neneng perihal desain merek tersebut, maka tim peneliti melakukan penyuluhan terlebih dahulu mengenai merek sesuai dengan undang-undang yang berlaku kepada Ibu Neneng. Pada tahap ini, disiapkan terlebih dahulu materi-materi yang akan disampaikan kepada Ibu Neneng supaya tepat sasaran dan sesuai dengan kebutuhan. Pada saat pemberian materi, kami tim peneliti mengamati, bahwa Ibu Neneng tampak antusias dan berusaha untuk mempelajari dan memahami materi yang disampaikan, sampai pada tahap dapat mengetahui dan mengerti tentang bagaimana aturan-aturan dalam membuat desain merek yang benar sesuai aturan yang ditetapkan oleh undang-undang. Ibu Neneng tampak senang dan bersyukur atas pengetahuan baru yang telah diterima dari tim peneliti. Setelah Ibu Neneng memahami tentang aturan-aturan dalam membuat desain merek, maka Dia menyampaikan keinginannya untuk membuat desain merek sandal Tumaninah yang baru agar dapat digunakan untuk mengganti merek lama yang keliru dalam desainnya. Sehubungan dengan tidak adanya orang di dalam kepengurusan BUMDes Niagara yang mampu untuk membuat desain merek sandal Tumaninah yang baru, maka akhirnya disepakati bahwa pihak yang akan membuat desain merek yang baru adalah tim pelaksana kegiatan. Berdasarkan wawancara tentang rencana apa yang akan dilakukan oleh BUMDes tentang produk sandal ini, ternyata Ibu Neneng sudah mempunyai rencana merancang strategi baru untuk pemasaran sandal Tumaninah sehingga beliau sangat antusias untuk segera mengganti desain merek Tumaninah yang lama dengan desain merek Tumaninah yang baru.

Permasalahan ke-2 berkaitan dengan adanya kekeliruan dalam surat kontrak bisnis yang telah disusun oleh Ibu Neneng. Berdasarkan wawancara dengan Ibu Neneng, dapat diketahui bahwa BUMDes Niagara melakukan kemitraan usaha dengan salah seorang warga desa, yaitu Bapak Roni, yang mahir di dalam bidang pembuatan sandal wanita dan sandal laki-laki dewasa. Ibu Neneng menjelaskan bahwa Dia telah membuat surat perjanjian usaha yang telah ditandatangani oleh Bapak Roni dan BUMDes Niagara, dimana BUMDes Niagara berperan sebagai investor dalam pembuatan sandal yang dikerjakan oleh Bapak Roni. Dalam kerjasama ini BUMDes Niagara memberikan Rp. 10.000.000 kepada Bapak Roni sebagai modal pembuatan. Bapak Roni bertanggung jawab atas seluruh urusan yang berkaitan dengan pembuatan sandal mulai dari pembelian bahan baku,

Jurnal REKSA: Rekayasa Keuangan, Syariah, dan Audit, Vol. 06, No. 02, 2019, pp 111-122| 119 
Trisa Nur Kania, Latifah Adnani | Legalitas Merek Dagang dan Kemitraan Usaha ...

bahan penolong dan lain-lain hingga berwujud menjadi sandal yang sudah siap untuk dikemas dan dijual. Sementara BUMDes Niagara membuat merek dagang dan menyiapkan dus kemasan serta mempromosikan produk sandal tersebut. Merek dagangnya adalah Tumaninah. Setelah tim peneliti melihat surat kontrak bisnis tersebut, ternyata di dalamnya memuat beberapa kekeliruan, sehingga tim peneliti memberi masukan untuk dapat diperbaiki. Berdasarkan kekeliruan yang telah terjadi di dalam surat kontrak bisnis tersebut, maka disepakati dengan Ibu Neneng agar segera diperbaiki. Berdasarkan kesepakatan tersebut tersebut maka dilakukan penyuluhan terlebih dahulu kepada Ibu Neneng tentang cara menyusun kontrak bisnis yang benar, hingga akhirnya Ibu Neneng dapat memahami dan akan membuat kembali surat kontrak bisnis yang baru setelah kontrak pertama berakhir. Menurut observasi yang kami lakukan, Ibu Neneng menyadari kesalahan yang sudah dia lakukan tampak bahwa beliau ini semangat untuk mempelajari hal baru yang dia anggap bermanfaat.

Permasalahan ke-3 berkaitan dengan keinginan untuk mendaftarkan merek dengan desain yang baru untuk sandal Tumaninah. Berdasarkan wawancara dengan Ibu Neneng, ternyata Ibu Neneng meminta tim peneliti untuk membantu mendaftarkan merek dagang sandal yang baru tersebut, karena beliau tidak memahami cara mendaftarkannya serta kegiatan pekerjaan harian di kantor BUMDes Niagara juga tidak mudah untuk ditinggalkan oleh Ibu Neneng. Oleh sebab itu, maka tim peneliti yang akan membantu mendaftarakan merek dagang sandal Tumaninah yang baru, terlebih dulu memberikan pendampingan dalam pembuatan surat kuasa untuk mendaftarkan merek dagang sandal yang baru tersebut. Adapun bukti dari pendaftaran merek dagang adalah terbitnya resi yang menjadi surat resmi sementara bagi pihak BUMDes Niagara untuk mulai membuat/mencetak label dengan merk Tumaninah yang baru secara formal.

Permasalahan ke-4 berkaitan dengan keterbatasan mempromosikan produk sandal Tumaninah walaupun sudah diberi label merek dagang oleh pengurus BUMDes Niagara. Berdasarkan wawancara dengan Ibu Neneng, diperoleh penjelasan bahwa penggunaan merek dagang sandal Tumaninah yang sudah didesain sebelumnya, sebenarnya memang belum diyakini dapat membawa keuntungan bagi BUMDes karena merupakan uji coba dan pengalaman pertama memasarkan produk sandal. Tetapi karena beliau dan pegawai Unit Perdagangan harus segera memasarkan produk sandal Tumaninah, akhirnya produk sandal tersebut memang sudah show-on di lemari pajangan yang ada di ruang kerja Unit Perdagangan kantor BUMDes Niagara dan dipasarkan dengan menggunakan promosi yang manual, yaitu mouth by mouth. Menurut penjelasan Ibu Neneng, produk sandal yang sudah terlanjur diberi label Tumaninah tersebut harus didorong untuk segera dipasarkan dan dibeli oleh konsumen agar uang modal yang ditanamkan di Unit Perdagangan dapat segera kembali dan dapat ditanamkan lagi pada unit usaha lain yang memerlukan tambahan modal. Jika didiamkan saja berarti usaha penjualan sandal ini tidak akan membawa keuntungan bagi BUMDes Niagara. Oleh sebab itu, sekarang setelah merek sandal Tumaninah yang baru telah didaftarkan secara formal kepada negara, maka peluang Ibu Neneng bersama Unit Perdagangan BUMDes Niagara akan menjadi lebih yakin dan lebih percaya diri untuk mempromosikan sandal Tumaninah dengan cara kekinian yang lebih trendy dan daya jangkau pemasaran yang luas yaitu melalui media sosial.

Jurnal REKSA: Rekayasa Keuangan, Syariah, dan Audit, Vol. 06, No. 02, 2019, pp 111-122 | 120 
Trisa Nur Kania, Latifah Adnani | Legalitas Merek Dagang dan Kemitraan Usaha ...

Berdasarkan wawancara dengan Ibu Neneng tentang rencana untuk mendorong pemasaran produk sandal Tumaninah, maka dapat diketahui bahwa dalam waktu dekat pengurus BUMDes Niagara sudah merencanakan akan mempromosikan sandal Tumaninah secara daring dengan harapan akan diperoleh wilayah pemasaran yang lebih luas dari sebelumnya. Bagi pengurus BUMDes Niagara kegiatan jual beli yang dapat dilakukan secara daring bukan hal yang sulit, karena di bawah Unit Perdagangan BUMDes sudah ada kegiatan penjualan jasa pengiriman paket RPX sejak awal tahun 2019. Dengan demikian kegiatan penelitian dan pengabdian yang dilakukan oleh tim pelaksana dapat memberikan manfaat yang positif bagi BUMDes Niagara.

\section{SIMPULAN DAN SARAN}

Wawasan pengetahuan pelaku usaha tentang peraturan merek dagang masih rendah khususnya yang terkait dengan pentingnya memahami aturan main dalam mendesain dan mendaftarkan merek dagang secara legal kepada negara melalui Ditjen HKI Kemenkumham. Oleh sebab itu, penyuluhan yang telah diberikan peneliti kepada Ibu Neneng telah mampu memberikan wawasan dan pengetahuan tentang legalitas merek dan kemitraan usaha. Selain itu dapat disarankan di sini bahwa pelaku usaha hendaknya tidak hanya memikirkan bagaimana membuat sebuah produk yang berkualitas dalam kegiatan bisnisnya supaya memperoleh keuntungan saja, tetapi pelaku usaha perlu juga mempelajari aspek-aspek hukum yang berperan dalam melindungi produk yang ditawarkan dan dijualnya kepada masyarakat. Selain itu, aspek lain yang perlu dipahami juga oleh pelaku usaha adalah aturan-aturan tentang kemitraan usaha, dimana kemitraan usaha berpeluang terjadi jika perusahaan melakukan sebuah tindakan kerjasama usaha dengan pihak-pihak lain yang berkepentingan dengan kegiatan bisnis yang dilakukan oleh pelaku usaha. Harapannya tentu saja agar hak dan kewajiban dari masing-masing pihak yang bermitra tidak dilanggar.

\section{DAFTAR PUSTAKA}

Ahmadi Miru, 2005, Hukum Merek Cara Mudah Mempelajari Undang-undang Merek, Jakarta : PT. Raja Grafindo Persada

https://prolegal.id/2018/06/26/mendaftarkan-merek-atau-brand-usaha-anda/

Mohammad Jafar Hafsah, 2000, Kemitraan Usaha, Konsepsi dan Strategi, Pustaka Sinar Harapan, Jakarta.

Mudjia Rahardjo, 2017, Studi kasus Dalam Penelitian Kualitatif : Konsep dan Prosedurnya, UIN Maulana Malik Ibrahim Malang, Program Pasca Sarjana.

Munir Fuady, 2012, Pengantar Hukum Bisnis Menata Bisnis Modern di Era Global, Bandung: Citra Aditya Bakti.

Robert K Yin, 2015, Studi Kasus : Desain dan Metode, Penerjemah : M. Djauzi Mudzakir, Ed I, Cet XIV, Jakarta : Rajawali Pers.

Sugiyono, 2017, Metode Penelitian Kuantitatif, Kualitatif dan RD, Cet XXV, Bandung: Alfabeta

Jurnal REKSA: Rekayasa Keuangan, Syariah, dan Audit, Vol. 06, No. 02, 2019, pp 111-122 | 121 
Trisa Nur Kania, Latifah Adnani | Legalitas Merek Dagang dan Kemitraan Usaha ...

Endang Purwaningsih Nelly Ulfah Anisa Riza Nurul Fajri Chikmawati, \& Fakultas. (n.d.). Kesadaran Hukum Terhadap Kepemilikan Merek Terdaftar Pada Pengrajin Batik Pekalongan Jawa Tengah,

PKDSP. (2007). Buku Panduan Pendirian dan Pengelolaan Badan Usaha Milik Desa (BUMDes). Buku Panduan Pendirian Pengelolaan Badan Usaha Milik Desa (BUMDES), $1-46$.

Sukmadewi, Y. D. (2018). KAJIAN LEGALITAS DAN MANAJEMEN MEREK PADA UMKM MUNAKU SULAM PITA SEMARANG. LAW REFORM, 14(2), 275. https://doi. org/10.14710/lr.v14i2.20874

www.hukumonline.com/pusatdata. (2016), 1-56. 